DOI: $10.1515 /$ rpp-2017-0001

Doctor of Pedagogical Sciences, Full Professor, Full Member (Academician) of NAPS of Ukraine, ROMAN GUREVYCH Mykhailo Kotsiubynskyi Vinnytsia State Pedagogical University Address: 32 Ostrozkyi St., Vinnytsia, 21001, Ukraine

$\mathrm{PhD}$ in Pedagogical Sciences, Full Professor, MAYA KADEMIYA Mykhailo Kotsiubynskyi Vinnytsia State Pedagogical University Address: 32 Ostrozkyi St., Vinnytsia, 21001, Ukraine E-mail: maj.kademija@gmail.com

\title{
BLENDED LEARNING AND INNOVATIVE TECHNOLOGIES IN TRAINING OF FUTURE SPECIALISTS IN FOREIGN HIGHER EDUCATION INSTITUTIONS
}

\begin{abstract}
The article characterizes one of the most promising models of blended learning in higher education institutions. The article describes the peculiarities of improving the education process, the formation of motivational and professional competency of future specialists as well as the usage of one of the models of blended learning - "flipped learning", within which the personal-oriented approach is implemented and the interaction between teacher and student significantly increases. On the basis of the analysis of specialists' training in higher education institutions in the USA, Germany, Austria, South Korea by means of the blended model with the usage of the "flipped" and ubiquitous learning, it has been found out that specialists' training using these technologies will facilitate the absorption of significant amounts of information, the realization of individual and cooperative activities of students, teaching by project technologies that enables to develop communicative skills of students. All this makes it possible to train future specialists to work in the informational society in accordance with the requirements of labour market.

Key words: e-learning, blended learning, competency, teaching methods, "flipped" learning, professional competency, project technologies, ubiquitous learning.

\section{INTRODUCTION}

To find the ways to improve education in terms of significant increasing of amounts of information is an important issue to obtain competencies and possibilities of their usage in different conditions. Therefore, scientists, teachers and methodologists around the world are working on the problem of improving the process of their obtaining, transferring and absorbing. Educators have to solve one of the most important issues, namely, receiving a significant amount of knowledge during training in higher education institutions and in addition to that the main emphasis is transferred to a student. Classes in higher education institutions are mostly oriented toward a student as an active participant in the education process; therefore, there is problem of improving the forms, methods and means of training.

One of the promising models of learning is blended learning, which is called differently - hybrid learning, corporate learning, portion learning. However, regardless of the name, the essence of it is to combine elements of electronic and traditional learning that allows using the advanced learning technologies in the education process in higher education institutions without abandoning the traditional technologies and methods. This
\end{abstract}


makes it possible to make the learning process more efficient and productive, to increase motivation and interest of students, to form professional competencies.

\section{THE AIM OF THE STUDY}

The purpose of the article is to examine the experience of the scientists from the USA, Germany, Austria, Canada, South Korea about the problem of blended learning in higher education institutions using the technology of "flipped" learning, ubiquitous learning as a promising model of training future specialists in higher education institutions.

\section{THEORETICAL FRAMEWORK AND RESEARCH METHODS}

The problems of training by means of blended learning in higher education institutions have been covered by scientists Ye. Andropov, V. Bykov, N. Dmitriievska, Yu. Kapustin, Ye. Konrakova, V. Kukharenko, M. Kurvits, O. Spivakovskyi, V. Tykhomirov; the usage of "flipped" learning has been considered in works of J. Bergmann and A. Sams (USA, 2000), J. Khandke, Ch. Shpannehel (Germany, 2008).

The implementation of ubiquitous learning in the education process of higher education institutions has been described by such scientists as B. Bruce, B. Cope, M. Kalantzis, D. Sung.

For the purpose of the study a set of such theoretical methods has been used: analysis, synthesis and generalization of scientific literature and Internet sources on the issue of future specialists' training in higher education institutions with the help of the blended model.

\section{RESULTS}

Within today's globalization and integration processes in education, as N. Nychkalo indicates, the burning issue is the interconnection of education systems of different continents, their multidimensionality, comparability and mutual recognition of the product an individual who is trained for active highly professional activities in different spheres (Ничкало, 2010). Exactly the implementation of innovative approaches to the organization and learning process in higher education institutions will provide an opportunity to train competent highly professional specialists.

Our experience shows that blended learning is such an innovative model of specialists' training.

Blended learning includes:

- classroom and extracurricular students' independent work using a learning management system LMS, that is an information system used to create, collect, save and transfer the content;

- a wide range of educational materials;

- interactivity;

- control of students' self-learning;

- flexible system of assessment of students' achievements.

The practical reorganization of the models of blended learning as a tool to improve the modern education involves the creation of new educational methods based on the integration of traditional approaches to the education process.

In the activities of a modern educator the ability to organize networking community takes a special place, namely, the possibilities to use Web 2.0 and Web 3.0 services, such educational technologies as electronic learning (e-learning), mobile learning (m-learning), "flipped" training (f-learning), ubiquitous learning (u-learning) in professional activities. The most common of these are electronic, "flipped" and ubiquitous learning. We would like to consider these technologies within this paper. 
"Flipped" learning is a kind of blended learning which proposes to change the traditional learning, work at home and in the classroom. Instead, students watch short video lectures online - independently studying theoretical material, and all classroom time is used to do practical tasks, to discuss some issues of the course.

"Flipped" learning has a certain resemblance to forestalling self-study when students study new educational material before its presentation by a teacher in lectures or practical classes. The main difference is that in forestalling proactive independent work a student independently performs search and creative activities outside the classroom, while in "flipped" learning students learn new material by means of information and communication technologies (ICT) and the teacher virtually is present and controls this process (video explanations, test questions, etc.).

Thus, "flipped" learning is a pedagogical model where the typical presentation of a lecture turns into its discussion, during which projects, debates, practical tasks and others are discussed.

As it is known, the authors of the technology of "flipped" learning are teachers of Chemistry Aaron Sams and Jon Bergmann (USA). In 2008 they began to record videos of their lectures and offer the students to study them at home.

In 2010 Clintondale High School in Detroit (USA) became the first "flipped" school, which completely works on the principle of "flipped" learning.

The development of network learning and appropriate technologies led to the usage of online learning where the synchronous interaction is in real time and all members of the education process are using the joint service. It can be live video transmissions, conference calls, Skype or chat, webinars. The asynchronous communication includes: email, forums, blogs, Facebook, Twitter and other social networks.

What does "flipped" learning give? It has been found out that:

- firstly, it contributes to better understanding of educational material, significantly improves the interaction with a teacher and other students and develops critical thinking;

- secondly, the classroom time is rationally used.

Educational videos, interactive classroom work, observations - feedback, assessment are used for effective implementation of "flipped" learning. It is clear that each of these components requires the development of additional educational and test materials.

How is this process going on? Students receive educational materials that can be placed on You Tube, Web-portal or Web-sites containing the texts of lectures, electronic guides, video lectures. This allows each student to learn the theoretical basics of a subject in any place, time and own pace. During the class, the educator gives practical tasks and additional materials required. While doing the tasks the students work individually, in pairs or groups, and the teacher only consults, explains complicated issues and assesses the students. Consequently, the students from being passive listeners move to participate actively in obtaining knowledge and it allows to take the responsibility for their knowledge, to control the education process and as the final result to control their own success.

While getting ready with video educational materials a teacher should take the following into consideration:

- the duration of the video should be 5-7 minutes;

- the video must contain one or two questions (tasks);

- video explanation should be interactive.

In "flipped" learning not only video lectures play an important role. Reviewing of sites, blogs, presentations, projects on topics under discussion and others are of particular importance. 
So, while studying the topic "Interactive Educational Technologies" the students during a Web-quest on the subject are discussing the issues of the interactive technologies of cooperative learning, such as the work in pairs, rotation in threes, two-four-all together; and also the interactive technologies of group learning such as "brainstorming", while teaching I study; situational modeling; controversial issues; information and communication technology of study and others.

The discussion of the technologies mentioned above is based on the examples in professional subjects, with corresponding traditions of using these technologies in the education process. The students offer their own critical attitude to solve the given problem.

Thus, while studying the issue of implementation of ubiquitous learning (u-learning) in higher education institutions the students participate in the project by means of the technology of Web-quest called "Ubiquitous learning". During this project the students get acquainted with wireless educational technologies via Internet sources which are located on the site of this project, they do the tasks, answer the questions and it enables them to explore, discover and present the key information, to design and present it in the proper way and also to prove and defend their point of view.

Thus, while performing such activity the students are in the center of the learning, during which they use not only their knowledge, but also can further explore the issue, learn complicated material with the support of the teacher.

During this work the responsibility is assigned to a student, all students can control the process of mastering the educational material, assess the results.

The idea of "flipped learning" is practiced together with such a type of learning that has been carried out for over six years by the teachers of the department of innovation and information technologies in education in Vinnytsia State Mykhailo Kotsiubynskyi Pedagogical University, namely, the students get acquainted with the new educational material previously at home which is located in electronic educational complexes, and then in class they consider problematic moments, consolidate the theoretical knowledge and develop practical skills. The assessment of mastering new educational material can be made, for example, by computer testing.

Currently $2 / 3$ of educational material is studied by students independently, so it is important to use modern means of learning that makes it possible to absorb this amount of educational material and students can also develop stable practical skills that are difficult to implement by the traditional means of classical pedagogy. So, it is necessary to look for the ways of intensification of performance classes. The proposed "flipped learning", in particular, rejects the traditional inefficient forms within the limited time in classes, such as students' reports, frontal questioning, dictating of ready-made notes, watching movies, presentations and so on.

This approach enables students to view course materials repeatedly at any time. Also, having a blog on the web-page of a particular subject enables to ask your own questions in the comments and receive answers.

In order to identify students' understanding of educational material at the beginning of the class, the teacher gives a number of questions, tasks that students have to answer. It gives the possibility to distinguish the questions that need to be scrutinized.

If there are electronic educational aids, the connection can be done to each video for a particular part of the guide and it can give students the opportunity to view video clips to each part of the guide many times. 
Instead, the elements of cooperation education are introduced: a teacher acts as a colleague, a counselor. Students master the course material, largely through independent study that promotes cognitive activity and independence. The main elements of the proposed method are:

- the use of concise electronic aids, guides;

- preliminary familiarization of students with new educational material out of class;

- a brief explanation of the new educational material from the textbook in class;

- assessment of students' skills while they are performing practical tasks;

- to develop and check the skills based on the educational material in the current

class;

- grading as combined point for the knowledge of the theory and practical skills;

- permission for students to use information materials during their work;

- introduction the means to prevent cheating;

- individual protection of students' practical papers;

The assessment is carried out at each session according to ECTS scale.

In the context of the "flipped learning" one can raise a question: how can students be interested in studying the educational material for the implementation when they perform common tasks not always well? Perhaps the only way to solve this problem is that video tutorials, video lectures or electronic guides used in this method should be interesting, rich and clear not only for teachers but also for students. The role of a textbook has changed fundamentally in the modern world today.

A textbook ideally should not only contain the actual material of the next lesson which, by the way, can be found anywhere on the Internet, but it should be interesting and understandable, it should correspond to the age peculiarities of information perception, take into consideration the interdisciplinary connections, contain videos and so on.

Electronic aids are very often composed by narrow specialists without consulting with programmers, designers, psychologists and without the level of educational achievement in other subjects taking into account. Therefore, it is important to create interactive electronic guides, to use sources of the Internet as well as to simulate the processes and phenomena that they consider.

In the process of using "flipped learning" by a teacher as an effective way to deliver the content he must be warned against the following errors:

1.2 or 3 short videos are better than one long video during which the main purpose is lost. It should not take more than 10 minutes to watch one video, the connection must be done to the appropriate section.

2. In order to focus students it is necessary to pay special attention to the colors of images and questions.

3. Sessions should be of gradual continuous nature and answer the question: why are they actual, what questions should be answered.

4. Sessions should be well organized and effective. Multiple viewing video and an electronic text or electronic guide will facilitate the combination of course material with the reality.

5. Grading of the results in an electronic register or Google form will help to monitor students' achievements.

6. Connecting of the external resources such as videos, web-links, etc. will help to ensure that students will see the significance of the material which is being studied. 
Thus, the term "flipped learning" is based on active learning, engaging students in joint activities, combined system of training, podcast. The value of it lies in the ability to use educational time for group sessions where students can discuss the content of a lecture, test their knowledge and interact with each other in their own practical activities. During the training sessions the teacher's role is to act as a tutor encouraging students to independent research and collaboration. Currently there is no common model of "flipped learning"; it is a term that is widely used in reviewing records of lectures followed by discussion in the classroom. Short-term training video lectures allow students to move through a topic in the pace comfortable for them, focusing on those moments that cause some difficulties and skipping those ones they are already familiar with. This will help to ensure that the students come to the class prepared, have the opportunity to participate in creative projects, Blog-quests and others. The technology of "flipped learning" allows students to control fully the course of lectures, common performance of projects; it helps in social interaction among students facilitating the process of information perception. In this process teachers' role and students' role are changed placing the responsibility on the students and encouraging them to experiments. In this process there is a shift of priorities from simple presentation of educational material to work on its improvement.

\section{CONCLUSIONS}

Thus, the experience of the USA, Germany, Canada, Austria and other countries as well as our own in training future specialists in higher education institutions by means of the blended learning model with the usage of the technology of "flipped learning" and "ubiquitous learning" enable students to receive qualitative knowledge and skills, to solve problems independently, to take and defend their own point of view, to be ready for the implementation of independent research.

The prospects of further research are the implementation and adaptation of the blended model of learning using innovative technologies in training competitive specialists in higher education institutions.

\section{REFERENCES}

1. Гуревич, Р. С., Кадемія, М. Ю., Козяр, М. М. (2012). Інформаиійнокомунікаиійні технології в професійній освіті майбутніх фахівиів [Information and Communication Technologies in Professional Education of Future Specialists]. Львів : Вид-во «СПОЛОМ», 380 p. (in Ukrainian).

2. Дмитриевская, Н. (2006). Инновации в образовании Кореи через e-learning [Innovations in Education of Korea Through E-learning]. Мир электронного обучения [E-learning world], No 6, pp. 20-23 (in Russian).

3. Курвиц, М. (2013). Переворачиваем обучение. Часть первая : предпосылки модели обучения "перевернутий класс» [We Flip the Learning. Part One: The Conditions of the Learning Model "A Flipped Class"]. Retrieved 17.11. 2016 from : http:edugalaxy. intel.ru/index/php?automodule=bloge=blo-gid $=28240$ showentry $=5351$.

4. Ничкало, Н. (2010). Науково-методичне забезпечення професійної освіти i навчання: прогностичний аспект [Scientific and Methodological Support of Professional Education and Training: a Prognostic Aspect]. In: Proceedings of the Reporting Scientific Conference on Scientific and Methodological Support of Professional Education and Training (29.-31.03.2010). К. : ІПТО НАПН України, pp. 4-8 (in Ukrainian).

5. Zillion - Образовательный ресурс [Zillion - Educational Resource] (2013). Blended learning: переход к смешанному обучению за пять шагов [Blended Learning: Transition to Blended Learning in Five Steps]. Retrieved 05.11.2016 from : http://zilion. net/ru/blog/375/bleandedlearning-pieriekhod-kmieshannomy-obuchieniiu-5-5shaghov. 